\title{
Municipal engineers in Johannesburg and Pretoria before 1910
}

\author{
H Mäki and Johannes Haarhoff*
}

\begin{abstract}
This paper examines the history of the first town engineers in Johannesburg and Pretoria by looking at the selection process that was applied in their appointment; their responsibilities; and the circumstances at the end of their tenures. It explores what was expected of municipal engineers in the late nineteenth and early twentieth centuries; shows how weak their position was within the municipal structure; and explains how vague their job description was in relation to their wide field of operation. It becomes clear that most early town engineers had no formal training for the positions they held and that there was added pressure from elected councillors in both municipalities who were prone to follow assiduously how officials were spending public money.
\end{abstract}

Keywords: Municipal history, civil engineering, water supply, sanitation, Johannesburg, Pretoria Disciplines: History, Engineering, Public Management

\section{Introduction}

The relationship that existed between local decision makers and officials in establishing municipal infrastructure such as water supply and sewerage systems was, and still is, an important issue affecting the development of these services. The status of the officials in the municipal hierarchy in the early years varied a great deal. The first municipal engineers were appointed in the $1850 \mathrm{~s}$ after municipalities were given the responsibility of developing and maintaining certain elements of infrastructure, of which water supply was one of the most important. With the discovery of diamonds and gold, large communities sprung up virtually overnight. Conditions in new mining towns were unsanitary and chaotic. The role of municipal engineers during these formative years has not been studied in great detail but what is clear is that they often seem to have borne the brunt of public frustration - frequently for urban problems not necessarily related to the provision of proper municipal services.

In England urbanisation began in the mid-eighteenth century, while in South Africa the process was delayed for nearly a hundred years. The development of local government met similar obstacles to those

* Dr Harri Mäki is a post-doctoral researcher in the School of Basic Sciences at the Vaal Triangle Faculty of the North-West University. E-mail: harri.maki@nwu.ac.za. J Haarhoff is a professor in the Department of Civil Engineering Science at the University of Johannesburg. E-mail: jhaarhoff@uj.ac.za. 
encountered in England but it appears that early South African municipal engineers did not reap the benefits of the experience of their counterparts in Britain. Rapid urbanisation called for strong local measures to ensure a safe and comfortable urban environment, but the people moving in from the countryside had little appreciation for the necessity of proper sanitary measures. It was the municipal engineer who had to cope with this opposition with little or no protection or support from elected councils. The forging of local government was indeed a process beset with difficulties. ${ }^{1}$

Finding qualified engineers was at first far from easy because there were very few resident in South Africa. This situation changed radically after the discovery of diamonds in Kimberley. Engineers from all over the world were lured to South Africa and later this trend increased when extensive gold deposits were found on the Witwatersrand in 1886. The schooling of engineers in South Africa only began after 1910 so originally most engineers came from Europe, especially the United Kingdom. The early engineers from the United Kingdom were trained via the apprenticeship system, because there was no formal training as such in municipal engineering. Even if an engineer held a university degree it was usually in mathematics or a related field.

In this article the focus will be on the first town engineers in Johannesburg and Pretoria before the establishment of the Union of South Africa in 1910. What were the criteria when the municipalities selected new town engineers? What were the expectations of individual candidates? How did the level of previous work experience (in the fields of water supply and sanitation works, for instance) influence the selection of a town engineer? What were the main problems they encountered and how did they deal with them? An investigation will also be made of how and why these municipal officials ended their tenures.

\section{Johannesburg prior to the Anglo-Boer War}

William Henry Miles: When the first town engineer was appointed in Johannesburg in October 1889, neither its sanitary board nor the mining commissioner was responsible for providing the local community with the basic services that they needed. ${ }^{2}$ When local services were required, the government of the Zuid-Afrikaansche Republiek, with its capital in Pretoria, favoured the policy of granting concessions, a policy that was widely practised in the country as a whole. ${ }^{3}$ In 1887 , a concession was granted for supplying water to newly established Johannesburg, and the next year a waterworks company was formed to exploit the concession. A similar gas concession was granted in 1888, and was soon followed by electricity and tramway concessions in 1889 . The proposal by W.H. Rogers, a member of the sanitary board, that in the light of the need for public works, they should advertise for a town engineer

1. J. Haarhoff and C. James, 'The First Conference of Municipal Engineers in South Africa on June 6-7, 1921', IMESA 2009 Conference, 28-30 October, 2009, Cape Town, 5-6.

2. In theory sanitary board was responsible for the sanitary conditions as well as all essential services like water, electricity, and transportation, but in practice in Johannesburg this responsibility was limited mainly in sanitary services and street building. Harri Mäki, Water, Sanitation and Health: The Development of the Environmental Services in Four South African Cities, 1840-1920 (Tampere: Kehrämedia Inc., 2008), 137-140.

3. Concessions are still a widely debated issue. See for instance, J.J. Hukka and T.S. Katko, Water Privatisation Revisited - Panacea or Pancake? (Delft: IRC International Water and Sanitation Centre, 2003). 
with a salary of $£ 1000$ per year, was unanimously accepted. ${ }^{4}$ William Henry Miles was chosen for this position and he assumed his duties in December 1889..$^{5}$ Miles came to Johannesburg from Bournemouth, England, but had worked in King William's Town and Port Elizabeth as an architect and engineer from 1878 to $1884 .^{6}$

With the appointment of a town engineer and a treasurer, the single sanitary department under the sanitary board was divided into two recognisable units, so that by July 1890 a new secretarial section was born. While retaining its previous responsibilities the sanitary department had engineering added to its duties. The secretarial department was concerned with both administrative and financial matters. ${ }^{7}$

The district surgeon, Hans Sauer, informed a sanitary board meeting in July 1889 that Johannesburg was second only to the Panama Canal region in its death rate. ${ }^{8}$ The climate on the Witwatersrand was healthy enough, yet the circumstances under which the mass of the people lived made typhoid endemic. The condition of watercourses, drains, and the management of the town were as bad as they could possibly be. The absence of supervision allowed every hollow to become a fever-generating marsh and every watercourse a channel for miasmatic poison. The new town engineer, W.H. Miles, was shocked at the deplorable sanitary state of the town when he arrived. In fact, his first task was the planning of a circular seven-man urinal on the Market Square. He thought that it might also be necessary to add a separate two-man contraption for black people. ${ }^{9}$

Miles pressed for the immediate removal of building materials and refuse that had been dumped in the streets, and asked for an assistant to help with this task. He then put in a request for the purchase of a steam-roller and submitted a plan for the stabilisation of Commissioner Street using rubble from the mine dumps. He also hired a stone-crusher and engine, and set about supervising the production of road material. The indefatigable town engineer (some were later to say he burnt himself out) also regularised street levels and the alignment of new buildings. In April 1890 he began putting up the first street name plates and by the following month he had his 10-ton roller operating. In the same year he became the leading light in the founding of a volunteer fire brigade, and in 1891 he supervised the laying of rails for the horse-trams. ${ }^{10}$

4. The Star, 29 October 1889.

5. 'The New Town Engineer', The Star, 27 November 1889. This was seen as so important an occasion that The Star wrote an editorial about the new appointment: 'The Man who Makes a Town', The Star, 12 December 1889.

6. William Henry Miles, in 'The South African Built Environment', http://artefacts.co.za/main/Buildings/ archframes. php?archid=1086, accessed 3.7.2009; 'Death of Mr W.H. Miles', The Star, 4 March 1893.

7. John R. Shorten, The Johannesburg Saga (Johannesburg: John R. Shorten Ltd, 1970), 450; J.S. Marais, The Fall of Kruger's Republic (Oxford: Clarendon Press, 1961), 54; T.V. Bulpin, Storm over the Transvaal (Cape Town: Howard Timmins, 1955), 162.

8. Quoted in L.E. Neame, City Built on Gold (Johannesburg: Central News Agency, [undated]), 41.

9. Percy Ward Laidler, and Michael Gelfand, South Africa: It's Medical History, 1652-1898, a Medical and Social Study (Cape Town: C. Struik, 1971), 407; Shorten, The Johannesburg Saga, 568, 569.

10. John R. Shorten, 'A History of the City Engineer's Department, Johannesburg 1886-1986', IMIESA, 10, (1986), 17. 
The disposal of the town's sewage was an ongoing problem for the sanitary board. The purchase of a new municipal dump became necessary when those living near the original dumping area (hired by the board) complained that the sewage was responsible for an 'insalubrious atmosphere'. Meanwhile, the excavations at the Brickfields area served as a convenient place to dispose of the dry refuse. On 26 February 1891, the town engineer submitted a comprehensive report on the issue to the sanitary board. Miles estimated the total quantity of sewage at 81 tonnes a day. His report embodied a plan whereby solids might be separated from liquid waste, prior to being incinerated in special furnaces. Liquid waste could be disposed of by depositing it in the outlying areas of the town. ${ }^{11}$ The sanitary board accepted the report and decided to carry out the proposals as soon as the necessary funds became available. As a preliminary step in this direction, the board resolved to ask for government assistance in buying 15 morgen of ground, a portion of Turffontein farm. Being situated three kilometres from the market square it was thought to be an ideal dumping site. Moreover, lying as it did in a hollow to the southeast of Johannesburg the prevailing winds would not carry any undesirable odours towards the town. The board felt that it was unlikely that there would be any complaints on the use of the site because it bordered on the Wemmer Gold Mine and little development had taken place in that direction. After careful consideration, the executive council decided to buy the ground on behalf of Johannesburg. ${ }^{12}$

With the dismissal of B. Malraison ${ }^{13}$ as secretary of the sanitary board and C. Serrurier ${ }^{14}$ as health inspector in 1891, M. Adolfs, the treasurer, was obliged to undertake secretarial work and Miles took over the duties of a health inspector. ${ }^{15}$ This was not a practical arrangement. The population of Johannesburg had grown so rapidly that the town engineer objected to the additional burden of health matters. It became clear that the combined duties were too onerous for one person, so the sanitary board decided to appoint a secretary and a health inspector. ${ }^{16}$

Pioneering work that Miles was carrying out so effectively with the new fire brigade was cut short in July 1892 when he was dismissed by the sanitary board for alleged serious neglect of duties in his capacity as town engineer. The sanitary board found his services in road building far from satisfactory. He was sued by the board for substantial damages and it was claimed that he had certified poorly-made streets as being up to standard. The judgment of the court went against Miles but according to The Star the investigation did not reveal any absence of professional competence or lack of integrity on his part. In fact The Star claimed that the majority of members of the sanitary board were guided by a mistaken sense of duty. Miles died shortly afterwards in March 1893. The Star expressed the opinion that his dismissal and the worries connected with the court case contributed in no small way to his death. ${ }^{17}$

11. The Star, 27 February 1891.

12. G.S. Burt Andrews, 'Valedictory Address by the President'. Proceedings of the South African Association of Engineers, 13 (1907-1908), 269; M.S. Appelgryn, Johannesburg: Origins and Early Management 1886-1899 (Pretoria: Unisa Press, 1985), 84, 86.

13. Harold Strange Library of African Studies (hereafter HSA), JMA, Notule [minutes] van vergadering van Gesondheidskomitee, 4 December 1891.

14. HSA, JMA, Notule van vergadering van Gesondheidskomitee, 23 October 1891.

15. Ibid., Korrespondensie van gesondheidskomitee, staatsekretaris aan waarnemende regeringskommissaris, 25 September 1891.

16. M.S. Appelgryn, 'Die Ontwikkeling van Plaaslike Bestuur in Johannesburg, 1886-1899’ (MA dissertation, Rand Afrikaans University, 1971), 163.

17. 'The Death of Mr W.H. Miles', The Star, 4 March 1893; Appelgryn, 'Die Ontwikkeling', 173; Shorten, 'A History of the City Engineer's Department', 17. 
When assessing the achievements of Miles as a town engineer it should be borne in mind that the central government had awarded many of the services that typically fell under a municipal engineer as concessions to private companies. In the case of Johannesburg these included the provision of water, gas and electricity. Miles' job description was limited to building and maintaining roads and improving sanitary conditions in the town. In both respects he had tackled these problems virtually upon arrival. However, the range of his responsibilities seems to have been rather too narrow - he became the driving force behind a newlyestablished fire brigade and spent increasing time and effort on it - apparently to the neglect of his official duties. As far as specific achievements are concerned, the most noteworthy were the regularised street levels; the first street name plates; and his memorandum on the disposal of the town sewage. The lack of progress on the latter appears to have been a lack of money on the part of the town.

The interim period: After Miles' dismissal, the engineering work was undertaken by two civil engineers in private practice, E.B.J. Knox and George R. Grey, who alternated as town engineer. ${ }^{18}$ On 2 December 1892, the sanitary board considered applications for the positions of town engineer, secretary-treasurer and health inspector. Of the 15 applicants for the post of town engineer, Grey was the unanimous choice. ${ }^{19} \mathrm{He}$ was born in India and went to school in Scotland and in the USA. He stayed on in the USA where he trained as an engineer and then worked in several South American republics. Upon arrival in South Africa, he worked for two years as assistant borough engineer in Durban before moving to the Transvaal. ${ }^{20}$

Before long Grey also fell foul of the sanitary board. At a meeting held on 10 March 1893 it emerged that he had turned down cheaper tenders for a particular project and accepted one that would be more profitable to him personally. The board saw this as a serious case of corruption and Grey was ordered to resign immediately, failing which he would be summarily dismissed. ${ }^{21} \mathrm{~A}$ decision was taken to advertise for a new town engineer. ${ }^{22}$ It is difficult to give any assessment of Grey's tenure as town engineer because it was so brief. He held the post for a mere four months and understandably did not make any lasting mark on the town.

Charles Aburrow: There were 33 applications for the vacant position of Johannesburg's town engineer within a week. ${ }^{23}$ The successful candidate was Charles Aburrow, ${ }^{24}$ who was appointed on 24 April

18. Shorten, 'A History of the City Engineer's Department', 17.

19. The Star, 2 December 1892; Appelgryn, 'Die Ontwikkeling', 192.

20. Men of the Times: Pioneers of the Transvaal and Glimpses of South Africa (Pretoria: Transvaal Publishing Company, 1905), 155.

21. These happenings did not have any adverse effects on Grey's popularity. In 1897, he was elected as a member of town council and continued in this position until the Anglo-Boer War. See Men of the Times, 155.

22. National Archives of South Africa (hereafter NASA), Transvaal Archives (hereafter TAB), SS, 3727, R5089/93, Extract uit de Notulen van byeenkomst van het Gesondheids Comité, 10 March 1893 and 17 March 1893; ‘The Town Engineer - A Curious Business', The Star, 11 March 1893; 'The Town Engineer', The Star, 17 March 1893.

23. The Star, 25 March 1893. Among the applicants were G.S. Burt Andrews and Ernst Lutz, of whom more later. Andrews had also applied for the position when Grey was chosen four months earlier. See The Star, 2 December 1892.

24. On Aburrow before and after his tenure as town engineer of Johannesburg, see L. Jackson and W. Martinson, Aburrow \& Treeby (Johannesburg: Parktown \& Westcliff Heritage Trust, 1989). 
1893. ${ }^{25}$ Three months later, in July 1893, G.S. Burt Andrews became the town's first building inspector. $^{26}$

Charles Aburrow was born in the UK and came to South Africa in 1879 to work as a chief surveyor for the London \& South African Exploration Company in Kimberley. He resigned his post in 1889 and moved to Johannesburg, where he opened a private practice. ${ }^{27}$ At the time, the primary functions of the town engineer were the construction and maintenance of roads and open spaces, and the strict enforcement of building regulations, which ensured that all new buildings in the town conformed to a reasonable standard. Water was supplied by the privately run Johannesburg Waterworks Company, so the town engineer had no responsibilities in that regard. His entire staff consisted of an assistant engineer, one technical assistant, a building inspector, a clerk, and a messenger. ${ }^{28}$

In September 1894, the sanitary board instructed Aburrow to prepare plans and make recommendations for a suitable sewer system to serve Johannesburg. In response, he presented a preliminary report in May 1895. ${ }^{29}$ In November, three experts, G.R. Andrews (the father of GSB Andrews, the building inspector), John Fletcher and H.C. Verner, were called in to give their opinion on Aburrow's suggestions. They submitted a written report which unanimously recommended acceptance of the scheme. ${ }^{30}$ In their report they also expressed the view that only the very latest methods in the field should be used in the construction process. ${ }^{31}$ The plan was duly approved but unfortunately in 1898 the government interfered by trying to grant the sewerage service to a private concessionaire. The stadsraad (town council) managed to sidestep this suggestion, but because of the outbreak of the Anglo-Boer War in October 1899, ${ }^{32}$ no further progress could be made with the sewerage system. ${ }^{33}$

Aburrow's work as a town engineer prior to the Anglo-Boer War was summarised by seven members of Johannesburg town council in 1901. They mentioned the proposed sewerage scheme as his most significant contribution. They also highlighted his efforts on the surface water drainage system, the proposed refuse destructors, abattoirs, fire brigade stations, public baths, the paving of streets and water supply schemes. They regretted that due to financial constraints some of these projects were not undertaken when Aburrow initially proposed them. ${ }^{34}$

25. Aburrow was chosen by 11 votes to 3 for E.B.J. Knox; NASA, TAB, SS, 3727, R5089/93, Extract uit de Notulen van eene speciale byeenkomst van Gesondheids Comité, 24 April 1893; Ibid., M. Adolfs to Eduard Bok, 25 April 1893.

26. HSA, JMA, Notule van vergadering van Gesondheiskomitee, 7 July 1893.

27. Jackson and Martinson, Aburrow and Treeby, 1.

28. Felix Stark, ed., Seventy Golden Years: Sewentig Gulde Jare, 1886-1956 Johannesburg: Municipal Public Relations Bureau, 1956), 354; George Grant and Taffy Flinn, Watershed Town: The History of the Johannesburg City Engineer's Department (Johannesburg: Johannesburg City Council, 1992), 60.

29. Grant and Flinn, Watershed Town, 60.

30. HSA, JMA, JARCH200A, Report of the Public Works Department, Johannesburg, 1895, 15-16.

31. HSA, JMA, JARCH272, Proposed Sewerage Scheme, Johannesburg, 21 November 1895, 7.

32. In some recent works, this conflict is referred to as the South African War. The debate on which name is more appropriate, is continuing.

33. Mäki, Water, Sanitation and Health, 259-60.

34. NASA, TAB, GOV, 19, GEN 459/02, J. Johnson Hoyle and D.F. Gilfillan to Chas. Aburrow, 3 July 1901. 
When the Anglo-Boer War began, Aburrow, a British subject, left Johannesburg and remained in the Cape Colony until October 1900. He offered his services should they be needed during the war. After the British troops had occupied Johannesburg, Aburrow was authorised by the new British administration of the Transvaal Colony to return as town engineer. ${ }^{35}$

\section{Pretoria before the Anglo-Boer War}

Ernst Lutz: Responsible municipal government was first mooted in Pretoria in 1880 during the British annexation of the Transvaal from 1877-1881. A proclamation by the then administrator, Owen Lanyon, gave a charter to the town and a municipal election was held. A dorpsraad (town council) was formed but the First Anglo-Boer War of 1880-81, which ended with the Boer victory at Majuba, meant that this was disbanded. In 1894 the magistrate suggested that Pretoria needed the services of a town engineer and the next year the auditor-general supported this idea by proposing that a town engineer should be appointed to take care of public works. ${ }^{36}$ The municipal affairs of the town, however, were controlled chiefly by the local landdrost (magistrate) until 1896. In December 1896, a temporary town council was appointed in terms of a proclamation issued by President Paul Kruger. The council of 11 members was assisted by Landdrost C.E. Schutte; Captain A. Schiel, the warden of the prison; Gordon B. Messum, the district surgeon; and Ernst Lutz, ${ }^{37}$ the first town engineer, who was named as the government's representatives. ${ }^{38}$

Despite the appointment of the council, there was little improvement in the sanitary conditions of the town. Matters reached such a critical point in June 1897 that the volksraad (the elected legislative assembly of the Transvaal Republic) appointed a commission of enquiry to look into the matter. The commission's report of September 1897 presented a bleak picture of the town's sanitation. ${ }^{39}$ Lutz was held accountable and was also blamed for exceeding his authority in the awarding of tenders. Among the reasons identified as responsible for this unsatisfactory situation were the lack of clear regulations, duties and accountability. ${ }^{40}$

The greatest problem was that the town engineer simply did not have the necessary resources to keep the town clean. The poor state of cleanliness, drainage of water, effective removal of dirt, and the repair of the

35. NASA, TAB, CS, 18, 2157/01, Charles Aburrow to G.V. Fiddes, secretary, Transvaal administration, 5 June 1901.

36. Cloete, 'Die Ontstaan en Ontwikkeling', 117.

37. The only information I have found about Lutz was that he is not originally from Transvaal; he applied for citizenship in 1894

38. The City of Pretoria and Districts. An Official Handbook Describing the Social, Official, Farming, Mining, and General Progress and Possibilities of the Administrative Capital and Surrounding Districts (Johannesburg: Publicity Department, South African Railways, 1913), 70-1; J.J.N. Cloete, 'Die Ontstaan en Ontwikkeling van die Munisipale Bestuur en Administrasie van Pretoria tot 1910', Archives Year Book for South African History, 1960, part 1 (Pretoria: Government Printer, 1960), 133.

39. Ibid., 120.

40. Cloete, 'Die Ontstaan en Ontwikkeling', 121. 
streets and sidewalks were discussed at length. All were under the surveillance of the town engineer. In the town council minutes of 18 March 1898 a comparison was drawn between the situation in Durban and that in Pretoria. Streets and drainage in Durban were apparently in far better condition than those in Pretoria. A decision was taken to ask the town council of Durban if their town engineer could spend some time in the Transvaal and give his Pretoria counterpart some technical advice. Durban agreed to this request and its town engineer, John Fletcher, arrived for a week in Pretoria. ${ }^{41}$

As noted above, accusations were made by the commission of enquiry that Lutz had awarded tenders without authority. He was eventually exonerated of misconduct and the blame was put on poorly defined jurisdiction and procedures. Nevertheless, he resigned shortly afterwards.

The assessment of Lutz's tenure, as in the case of Grey's term of office in Johannesburg, is hampered by a short employment period and a vague and limited description of the powers of the town engineer.

August Karlson: The Waterworks Company in Pretoria supplied piped water to the town's residents, alongside the old original supply which flowed in furrows along either side of the streets; this water was used to irrigate the gardens. ${ }^{42} \mathrm{H}$. Eckstein \& Co. owned the monopoly to supply water and the Pretoria Light \& Water Co. was formed to exploit this concession. After the creation of a temporary town board, it was proposed that Eckstein's monopoly should be terminated. A government commission was appointed by the volksraad in August 1898 and the outcome was that the government finally agreed to expropriate the company. ${ }^{43}$ The provision of water, electricity, tramways, markets, and even the sanitary service, had been granted to various individuals in the form of concessions. This was the status quo when the Anglo-Boer War broke out. ${ }^{44}$

By December 1898 the town council realised that they needed a new town engineer and a request to make the appointment was lodged with the state secretary. ${ }^{45}$ August Karlson, a Swede, was at the time the manager of the Waterworks Company and the members of the temporary town board asked him to apply for the engineer's post. The town was planning to take over the waterworks and the intention was to combine the work of the manager with the position of town engineer. ${ }^{46}$ Pretoria's second town engineer thus took office in June 1899.

41. S.P. Engelbrecht, J.A.I. Agar-Hamilton, A.N. Pelzer and H.P.H. Behrens, eds, Pretoria (1855-1955): History of the City of Pretoria (Pretoria: City Council of Pretoria, 1955), 52.

42. Report of the Witwatersrand Water Supply Commission 1901-1902 (Pretoria: Government Printer, 1902), 66.

43. A.H. Duminy and W.R. Guest, eds., Fitzpatrick, South African Politician: Selected Papers, 1888-1906 (Johannesburg: McGraw-Hill 1976), 492, ref. 19.

44. City of Pretoria and Districts, 72 .

45. NASA, TAB, SS, 7594, R16031/98, J. Bosch to the state secretary, 2 December 1898.

46. NASA, TAB, MGP, 86, 3870/01, August Karlson to Major-General Maxwell, military governor, Pretoria, 15 April 1901. 
He was exceptionally well qualified, as is apparent in his summary of his qualifications and experience, compiled in 1902:

I hold a diploma as Civil Engineer of Stockholm, Sweden. I am a Member of the Technical Institute of Sweden, a Member of the Sanitary Institute and of the Royal Institute of Health, London. I have had eleven years' practise as Railway Engineer and Bridge Constructor in Sweden, France and the Transvaal, four years on hydraulic and hydrographic work in the Isthmus of Panama, three years as Assistant Chief Engineer to the Municipality of Bordeaux, and four years as Waterworks and City Engineer of Pretoria. I have travelled for a considerable time in Europe and the United States for professional studies. I have made up projects for water distribution and drainage for several other towns. ${ }^{47}$

Karlson had been in the Transvaal since 1892, first as chief engineer responsible for surveying railway lines and then from 1898 as manager of the Pretoria Waterworks Company, which position he continued to hold for the entire time that he was employed as town engineer, because the plans for combining the two positions were shelved during the war. ${ }^{48}$ In 1897 he also devised a plan for a sewerage system for Johannesburg in response to an instruction by State Secretary W.J. Leyds. ${ }^{49}$

\section{The immediate aftermath of the Anglo-Boer War}

Aburrow's dismissal: After the British takeover of Johannesburg the incumbent personnel of the town council was retained on condition that, because of the uncertainty of the times, they might be dismissed on short notice once matters had normalised. On 22 May 1901, however, a decision was taken that the staff that had made themselves available would be re-appointed. ${ }^{50}$ This decision expressly excluded the town engineer, Charles Aburrow.

Aburrow carried out the duties of town engineer until May 1901, when, in his own words: 'to my astonishment I was informed by Major O’Meara that under the Municipality proclamation he could not allow me to remain in office. ${ }^{51}$ Aburrow then suggested that he stay on until a successor was appointed but was informed that this could not be allowed, and the next day, 30 May, he was summarily dismissed. On 5 June 1901 Aburrow complained about his treatment to G.V. Fiddes, secretary of the Transvaal administration. ${ }^{52}$ He persisted with his letters of complaint to the administrative headquarters of the Transvaal Colony in Pretoria, but in vain. ${ }^{53}$ According to W.A.J. O'Meara the re-appointment of

47. Report of the Witwatersrand Water Supply Commission, 123.

48. The Transvaal Civil Service List, 1906 (Pretoria: Government Printer, 1906), 188; NASA, TAB, MGP, 86, 3870/01, August Karlson to Major-General Maxwell, military governor, Pretoria, 15 April 1901.

49. NASA, TAB, SS 5742, R5582/97, August Karlson: Algemeen riolering plan van Johannesburg.

50. Lionel Curtis, With Milner in South Africa (Oxford: Basil Blackwell, 1951), 234.

51. Major W.A.J. O'Meara was first government commissioner and acting mayor of Johannesburg from 1900 to 1903; NASA, TAB, CS, 18, 2157/01, Charles Aburrow to G.V. Fiddes, secretary, Transvaal administration, 5 June 1901.

52. Ibid.

53. NASA, TAB, CS, 25, 3286/01, Charles Aburrow to T.H. Stopford, private secretary to the secretary of the Transvaal administration, 16 July 1901. 
Aburrow was impossible because he had not been able to work in harmony with the other departments. O'Meara made no reference to Aburrow's competence or his technical qualifications. ${ }^{54}$ Aburrow later received a letter signed by seven members of the town council expressing their regret and saying that the appointment of the town engineer was now in the hands of the governor, Alfred Milner. They praised Aburrow for his endeavours as a town engineer prior to the outbreak of the Anglo-Boer War. ${ }^{55}$

When Aburrow appealed to the Transvaal secretary his response was that he did not see his way clear to interfere in a municipal matter. ${ }^{56}$ Aburrow was nevertheless advised that he could send an application to the governor (who was away at the time) for the position of town engineer of Johannesburg. ${ }^{57}$ In the light of this, he agreed to refrain from taking any further steps until the governor returned. However, he did plan to make a submission to Milner on the damage to his reputation as an engineer and the pecuniary losses he had suffered because of his dismissal without the stipulated three months prior notice. ${ }^{58}$ On 19 September, Aburrow wrote to the governor pleading that his professional reputation be restored in the eyes of public. ${ }^{59}$ However, Milner replied that there was nothing he could do; he simply reiterated the opinion of the town council of Johannesburg assuring Aburrow that there was nothing in their decision of 29 May that reflected upon his reputation as an engineer. ${ }^{60}$

During this entire process, Aburrow kept the Association of Municipal and County Engineers in London fully informed on the issue. ${ }^{61}$ When advised by his lawyers that there was no recourse to the law because martial law was in force in the Transvaal at the time, Aburrow asked the association to put the matter before Joseph Chamberlain, the Secretary of State for the Colonies. ${ }^{62}$ All the information was duly sent to Chamberlain, asking for his assistance. ${ }^{63}$ Chamberlain enquired about the matter but was unable to make any headway. Milner and the town council simply pointed out that none of the pre-war staff had been given a pledge that they would be re-appointed. Strictly speaking Aburrow had thus not been dismissed. ${ }^{64}$

When reading Lionel Curtis' book With Milner in South Africa, there is little doubt about who was behind Aburrow's dismissal and with whom Aburrow could not work in harmony. On 11 April, Curtis wrote that he was 'most anxious that the present officials should be superseded by men of

54. Ibid., W.A.J. O’Meara, to the secretary of the Transvaal administration, 22 July 1901.

55. NASA, TAB, GOV, 19, GEN 459/02, J. Johnson Hoyle and D.F. Gilfillan to Chas. Aburrow, 3 July 1901.

56. NASA, TAB, CS, 25, 3286/01, Secretary of the Transvaal administration to Charles Aburrow, 3 August 1901.

57. Ibid., E.H.L. Gorges for the secretary of the Transvaal administration to Charles Aburrow, 8 August 1901.

58. NASA, TAB, CS, 31, 4180/01, Charles Aburrow to the secretary of the Transvaal administration, 22 August 1901.

59. NASA, TAB, GOV, 456, PS 86/01, Chas. Aburrow to the private secretary of the governor of the Transvaal, 19 September 1901.

60. Ibid., Private secretary to Charles Aburrow, 5 October 1901 and Lionel Curtis, acting town clerk to private secretary to the high commissioner, 2 October 1901.

61. NASA, TAB, GOV, 19, GEN 459/02, Chas. Aburrow to the secretary, Association of Municipal \& County Engineers, 19 July 1901, 16 August 1901 and 23 August 1901.

62. Ibid., Chas. Aburrow to the secretary, Assoc. of Mun. \& County Engineers, 5 April 1902.

63. Ibid., Thomas Cole, secretary of the Assoc. of Mun. \& County Engineers, to Joseph Chamberlain, secretary of state, 3 June 1902.

64. NASA, TAB, GOV, 456, PS 86/01, Milner, governor of the Transvaal Colony, to Joseph Chamberlain, Colonial Office, London, 31 August 1902. 
unimpeachable honesty and long experience of municipal needs'. He singles out the treasurer, town clerk and town engineer. ${ }^{65}$ Then on 25 July Curtis wrote: 'we have got rid of the men who were at the head of the Treasury, the Engineer's Department, the Fire Brigade, the Health Department ... Some of the men were corrupt heirlooms from the old administration, others had been put in by the new as a reward for political service and were utterly inexperienced in their duties'. ${ }^{66}$ It is clear that Curtis suspected that Aburrow was dishonest and corrupt.

A proclamation of 16 January 1901 had clearly stipulated that the important posts in the municipality were under the governor's jurisdiction and that the town council had no authority over them. All the personnel were appointed on a temporary basis and this also applied to the town engineer. The town council could not re-appoint Aburrow and Milner chose not to do so, which meant that Aburrow lost his job. ${ }^{67}$ Furthermore, the officials under the town council were now all English-speaking. There was a policy that without exception all the important positions were to be filled by staff from Britain. This was the case as far as the assistant town clerk, town engineer, town treasurer and medical officer of health were concerned. ${ }^{68}$

In assessing Charles Aburrow as a town engineer it should be remembered that he had to contend with the same limitations as did his predecessors. During his tenure the health board and later the town council were actively working towards establishing the town's own water supply so unlike Miles or Grey, Aburrow spent considerable time inspecting various proposals for water supply schemes, none of which were realised. Among the projects he undertook were the construction of the surface water drainage system, abattoirs, fire stations, public baths and the paving of streets. His most significant achievement was his proposal for the town's sewerage scheme. Unfortunately, due to various circumstances, his plans did not see the light of day.

Karlson and Pretoria: August Karlson held office as town engineer of Pretoria until 1902; was the manager of Pretoria Waterworks until 1903; and acted as a consulting engineer for the municipality from 1902 to $1904 .{ }^{69}$ The reason for Karlson's transfer from town engineer to a consulting capacity was not because of any dissatisfaction about the standard of his work or his ability as an engineer. Rather, it was because he was 'wanting in organising power', and that 'instead of extracting from his subordinates the duties and labour due from them', he preferred 'being a martyr to labour himself, rather than enforce that authoritative control and direction, which ensures a proper distribution of work, and the due discharge of duty'. In other words, he was deemed unable to delegate some of his responsibilities to his subordinates. This was the explanation given by R. Kelsky Loveday, the chairman of Pretoria municipality in 1902 when

65. Curtis, With Milner in South Africa, 214; see also Deborah Lavin, From Empire to International Commonwealth: A Biography of Lionel Curtis (Oxford: Clarendon Press, 1995), 39; and Elaine Mayo Paul, 'Lionel Curtis and the Unification of South Africa, 1901-1909' (PhD Thesis, University of South Carolina, 1978).

66. Curtis, With Milner in South Africa, 237.

67. A.J. Potgieter, 'Die Ontwikkeling van Stedelike Bestuur in Johannesburg, 1900-1910' (MA dissertation, RAU, 1976), 170-1.

68. Ibid., 171.

69. Civil Service List 1906, 188. 
he asked the Public Works Department to appoint Karlson as a hydraulic engineer. ${ }^{70}$ Loveday's letter was probably in reply to Karlson's application for the position of town engineer. ${ }^{71}$ As a consulting engineer Karlson's main task was to prepare a plan for the extended water supply for Pretoria. This he completed in December $1903 .{ }^{72}$

Karlson continued to work on various projects outside Pretoria during and after the Anglo-Boer War. In 1901-1902 he compiled a report on the water supply of Potchefstroom on the orders of Alfred Milner. ${ }^{73}$ Karlson was also interviewed by the Witwatersrand Water Supply Commission of 19011902. He was the only individual singled out in the introduction to their final report. ${ }^{74}$ Milner apparently valued Karlson highly since he mentioned him later in 1902 as a possible candidate for the position of the first chief engineer of the Rand Water Board. ${ }^{75}$ In 1904 Karlson was appointed as a hydrographic surveyor in the Department of Irrigation in the Transvaal colonial government. ${ }^{76}$ In this capacity in 1905 he recommended the building of Hartbeespoort Dam and was later responsible for its construction work until $1921 .{ }^{77}$ In 1910 he issued an unsuccessful plea to the city councillors and leading citizens for fountains, flowers and attractive paving for Church Square. Instead the square was re-designed as a tram terminus. ${ }^{78}$

A closer look at Karlson's career shows that he was highly respected as an engineer. He did a great deal of work as a consultant before, during and after his tenure in Pretoria. It appears however that he was not entirely at ease as a departmental head and was unable to delegate duties to others. Furthermore, the Anglo-Boer War was a disruptive factor for the greater part of his tenure, so it is understandable that little progress was made in the town at the time.

\section{New Men at the Helm}

Donald Calder Leitch and G.S. Burt Andrews: In December 1901 the administrator of the Transvaal sent a telegram to Joseph Chamberlain asking that the Colonial Office advertise the post of town engineer

70. NASA, TAB, PWD, 24, 763/02, R. Kelsky Loveday to Public Works Department, [first page of letter missing, probably March 1902].

71. NASA, TAB, CS, 73, 2239/02, August Karlson to the secretary of the Transvaal administrator, 10 March 1902.

72. Report of the Town Engineer, in Minute of His Worship the Mayor for the Mayoral Year ending 29th October 1904 (Pretoria: Wallachs, 1904), 47-8. The decision to realise this scheme was made only in 1909. Minute of His Worship the Mayor for the Mayoral Year ending 27th October, 1909 (Pretoria: Wallachs, 1910), 32-3.

73. NASA, TAB, TPB, 661, TA1552, August Karlson, city engineer, Pretoria, to the administrator of the Transvaal and Orange River Colonies and high commissioner of South Africa, 4 December 1901 and 4 January 1902.

74. Report of the Witwatersrand Water Supply Commission, iv.

75. NASA, TAB, GOV, 112, GEN 244/02, Milner to Joseph Chamberlain, Colonial Secretary, 15 June 1902.

76. Civil Service List 1906, 114.

77. The Building of Hartbeespoort Dam: Monument to a Visionary', Kormorant, Hartbeespoort's First Online Newspaper, 23 July 2009. http://www.kormorant.co.za/2009/07Jul/23Jul/Hartbeespoort\%20Dam.htm. (accessed 29.7.2009).

78. Vivien Allen, Kruger's Pretoria: Buildings and Personalities of the City in the Nineteenth Century. 2nd edition (Pretoria: Protea Book House, 2007), 43. 
of Johannesburg at a salary of $£ 3000$ per year. ${ }^{79}$ Among the applicants for the position were Thomas Bennett, engineer and manager of Cape Town Districts Water Works Company since 1893; S.E. Burgess, who had been borough engineer and surveyor to the County Borough of South Shields in the UK since 1898; W.P. Bannister from the Port Elizabeth Cold Storage Company; and William Dyack, borough surveyor and water engineer of Aberdeen in Scotland since $1892 .{ }^{80}$ The position was offered to T. de Courcy Meade, the city surveyor of Manchester but he later withdrew his candidature. ${ }^{81}$ The threeman selection committee thought that the next best candidate was D.C. Leitch, assistant director of the Architectural and Engineering works in the Admiralty. At the time two other candidates from the UK were mentioned: a man called Edge, from Newcastle and John Alexander Brodie, town engineer of Liverpool, who although said to be best municipal engineer in Britain, was thought to be 'too expensive'. ${ }^{82}$

D.C. Leitch was duly appointed town engineer of Johannesburg in June 1902. He was instructed that the town council desired that he should spend two or three weeks investigating certain sewage systems in the UK before leaving for South Africa. ${ }^{83}$ In the post-war city the returning citizens and the renascent press criticised the council as a 'debating society' and the imported officials as mere novices. The new immigrants included Charles Porter (the new medical officer), Leitch (the city engineer), and Lionel Hichens who had returned early in 1902 as city treasurer. ${ }^{84}$

In 1903, the control of sewerage management in Johannesburg reverted to the town council and it was decided to lay down a system of sewers. ${ }^{85}$ In 1913, G.S. Burt Andrews recalled that the building process was not an easy one: 'The drainage work in Johannesburg is carried out on a separate system ... Although the idea is not entirely original, I believe this is the first town of any size which has adopted it generally. In the early stages of the work it gave rise to a considerable amount of hostile criticism.' The system, however, turned out to be a success. Andrews gave the credit for this to Leitch, 'who, in spite of much opposition, had the courage of his convictions and was not afraid of starting a new thing'. Andrews confessed that at first he too had been sceptical about the proposal. ${ }^{86}$

In December 1904 Leitch was appointed as the first chief engineer of the Rand Water Board and G.S. Burt Andrews succeeded him in Johannesburg in 1905, serving until 1927. He had come to Johannesburg

79. NASA, TAB, CS, 53, 7093/01, Telegram from administrator to secretary of state, 4 December 1901; Curtis, With Milner in South Africa, 328.

80. Applications and references of all these applicants are available in NASA, TAB, GOV, 456, PS 86/01.

81. NASA, TAB, CS, 71, 2046/02, Empty folder marked: Appointment of Municipal Engineer, Johannesburg. Enclosing a copy of telegram to secretary of state, re offering above appointment to Meade, engineer of Manchester. Also next six folders (CS 73 2271/02; 76 2675/02; 79 3012/02; 81 3282/02; 82 3443/02 and $965603 / 02$ ) dealing with the appointment of municipal engineer for Johannesburg are empty. Archive staff members were unable to locate them; NASA, TAB, GOV, 456, PS 86/01, Telegram from secretary of state, London, to high commissioner, Johannesburg, 7 March 1902.

82. NASA, TAB, GOV, 456, PS 86/01, Telegram from secretary of state, London to high commissioner, Johannesburg, 7 March 1902; and cablegram from administrator to secretary of state, 11 April 1902.

83. NASA, TAB, GOV, 17, GEN 356/02, Fred Graham to D.C. Leitch, 15 May 1902.

84. Lavin, From Empire, 49.

85. Grant and Flinn, Watershed Town, 61.

86. G.S. Burt Andrews, 'Sewerage and Refuse Disposal in Johannesburg', The African Architect, May 1913, 204-5. 
from the UK in 1889 and worked in the town engineer's office from 1893, first as building surveyor, then as assistant town engineer under Aburrow and finally as deputy town engineer under Leitch. ${ }^{87}$ Earlier he had worked for four years with the Bournemouth Improvement Commissioners and another four years at Hornsey Local Board, in London. ${ }^{88}$

Leitch's sole achievement as town engineer of Johannesburg was overseeing the construction of a sewerage system for the town. His system was quite controversial at the time but proved highly successful. Most of Andrews' tenure falls outside of the scope of this research so a full assessment of his achievements in Johannesburg is not made here.

Hugh Daniel Badcock: The choice of a new town engineer for Pretoria was made between two candidates in 1902. The municipal council favoured George Bastable Laffan, who had been town engineer of Pietermaritzburg 1898-1901 and thus had experience in South African conditions. ${ }^{89}$ The colonial government, however, preferred Hugh Daniel Badcock, a British engineer, who was younger than Laffan. ${ }^{90}$ Badcock was duly appointed, although regrets were voiced from the Pretoria town council that the colonial government had not agreed to their suggestion. ${ }^{91}$ Badcock had come to South Africa in 1900 with the Imperial Yeomanry, and in October of the same year he was appointed as an assistant engineer to the town council of Pretoria. In July 1901, he was appointed to the Department of Mines of the Transvaal as an inspector of machinery in Germiston District. ${ }^{92}$

From the outset Badcock had to tackle the old problem of building and maintaining roads without surface water drainage. ${ }^{93}$ Granite kerbing, concrete guttering and paved footpaths were installed for the first time. Sound bridges were also constructed across the streams to make the city passable during wet periods. ${ }^{94}$ Badcock also saw the need for proper channelling of the streams to avoid possible flooding. This project was started in 1905.95

Badcock also prepared a proposal for a comprehensive drainage scheme. ${ }^{96}$ Work on this scheme began

87. Report of the Witwatersrand Water Supply Commission, 60.

88. Ibid., 64 .

89. NASA, TAB, CS, 73, 2196/02, R.K. Loveday, to the asst. secretary to the Transvaal administration, 7 March 1902.

90. Ibid., Acting secretary to the Transvaal administration to the chairman, Municipal Council Pretoria, 4 April 1902.

91. NASA, TAB, CS, 83, 3568/02, Johan S. van Reesama, acting town clerk to the acting secretary to the Transvaal administration, 17 April 1902.

92. NASA, TAB, CS, 74, 2429/02, H.D. Badcock to the assistant secretary to the Transvaal administration, 10 March 1902.

93. What follows is a brief overview of what Badcock accomplished as a town engineer of Pretoria. A more detailed description will be provided in a forthcoming article on the development of water services in Pretoria between 1855 and 1935, by Johannes Haarhoff, Harri Mäki and Petri Juuti.

94. P.F. Retief and N. de V. Loubser, Pretoria City Engineer's Department - the First Hundred Years, undated copy without publishing information, 17, 19.

95. Mayor's Minute, Pretoria, 1909, 20.

96. Cloete, 'Die Ontstaan en Ontwikkeling', 202. 
in June 1906. ${ }^{97}$ The first plans for sewage collection and treatment were made between 1904 and 1906. After approval in 1906, ${ }^{98}$ there were several delays in execution, for instance, when the governor vetoed the place suggested for a sewage disposal works. ${ }^{99}$ Nevertheless, a start was made on some of the necessary construction work. ${ }^{100}$

One of the reasons why many of the projects mentioned above were delayed was the retrenchment policy adopted by the town council in 1907; certain officials were dismissed and the salaries of others were reduced. ${ }^{101}$ For the town engineer's department it also meant re-organisation, with most of the previous departments combined as a new Works Department. The only one to survive as an independent section was a Drainage Department. This retrenchment might have been one of the reasons for Badcock's resignation in 1908. ${ }^{102}$ Although he officially remained on as town engineer until his successor, F. Walton Jameson, ${ }^{103}$ took over in March 1909, Badcock did not, for example, compile the town engineer's report for $1908 .{ }^{104}$

It could be said that Badcock began in Pretoria with a clean slate. As was the case in Johannesburg, limitations on the town engineer's powers were removed in the aftermath of the Anglo-Boer War when the concessions granted by Kruger's government were cancelled. Badcock made extensive plans for road building, construction of bridges, channelling of streams and improvement of the town's drainage and sewers. However, most of these plans were sidelined and then postponed because of lack of funds. Only road and bridge building were completed without excessive delay. Channelling of streams was begun in 1905 and the drainage scheme in 1906 but both were still under way when Badcock resigned in 1909. And although the sewerage plan was approved in 1906 only the filters were ready by 1909 . There was considerable opposition to the newly approved sewerage system, especially on the location of disposal works. Issues such as these continued to delay the process and eventually sewerage works were only undertaken during Jameson's tenure after 1910. Indeed, it could be claimed that Badcock did not achieve a great deal during his time in Pretoria. As for Jameson, assessment of his role, as is the case with that of Andrews, falls outside the scope of this paper.

97. Hugh Daniel Badcock, 'The Storm-Water Drainage of Pretoria', Minutes of Proceedings of the Institution of Civil Engineers, 183 (1911), 277.

98. Retief and Loubser, Pretoria City Engineer's Department, 23.

99. Minute of His Worship the Mayor for the Mayoral Year ending 30th October, 1907 (Pretoria: Wallachs Printing and Publishing Company, 1908), 16-17.

100. Retief and Loubser, Pretoria City Engineer's Department, 21.

101. Mayor's Minute, Pretoria, 1907, 51.

102. Badcock's mailing address was to England from August 1908, and from March 1909 to 1913 he was a commissioner of works at Suva, Fiji. E-mail message, Carol Morgan, archivist of the Institution of Civil Engineers in London, 31 July 2009; See also Joseph H. Elgie, Star and Weather Gossip concerning the Heavens, the Atmosphere, the Sea (London: Joseph H. Elgie, 1915), 70. Badcock also served as a platoon commander in the First World War. His career after the war is unclear.

103. Jameson served his articles as civil engineer under John Fletcher, borough engineer of Durban. Then he studied for some years in Britain, Canada, and the USA, and occupied professional position in England. After returning to South Africa he served as a waterworks engineer in Durban before he was invited to fill a position of a borough engineer of Pietermaritzburg from 1902. He remained in Pretoria until 1920, when he was invited to Kimberley as town engineer. He remained there for 11 years. Thereafter he was town engineer of Krugersdorp for one year. NASA, Western Cape Provincial Archives, 3/CT, 4/1/5/778, G457/5, 14, City of Cape Town, Application for post of city engineer and surveyor from Frank Walton Jameson, 31 May 1933.

104. Report of the Town Engineer, in Minute of His Worship the Mayor for the Mayoral Year ending 28th October, 1908 (Pretoria: Wallachs Printing and Publishing Company, 1909), 27-9. 


\section{Conclusion}

During the period researched in this article, there were five town engineers in Johannesburg and four in Pretoria. Two of them, Badcock and Karlson, had a university education. Grey, Aburrow, Andrews and Jameson had been trained through apprenticeship. The educational background of Miles, Leitch and Lutz is unclear but it is highly probable that they also had at least a similar level of training as the others.

\begin{tabular}{|c|c|c|c|}
\hline & Tenure & Qualifications & Reason for exit \\
\hline \multicolumn{4}{|l|}{ Johannesburg } \\
\hline William Henry Miles & 1889-1892 & $\begin{array}{l}\text { Architect and civil engineer, member of the Society } \\
\text { of Architects and of the Institution of Mining Engi- } \\
\text { neers }\end{array}$ & $\begin{array}{l}\text { Dismissed for al- } \\
\text { leged misconduct }\end{array}$ \\
\hline George R. Grey & $1892-1893$ & Learnt trade in the USA. & $\begin{array}{l}\text { Forced to resign } \\
\text { because of mis- } \\
\text { conduct }\end{array}$ \\
\hline Charles Aburrow & $1893-1901$ & No formal education, learnt trade by working & Dismissed \\
\hline Donald Calder Leitch & 1902-1904 & $\begin{array}{l}\text { Assistant director, Architectural and Engineering } \\
\text { Works, Admiralty; no municipal experience }\end{array}$ & $\begin{array}{l}\text { Resigned because } \\
\text { of the other work }\end{array}$ \\
\hline G.S. Burt Andrews & $1905-1927$ & $\begin{array}{l}\text { Trained as assistant in engineer's department, } \\
\text { Bournemouth Improvement Commissioners }\end{array}$ & Retired \\
\hline \multicolumn{4}{|l|}{ Pretoria } \\
\hline Ernst Lutz & $1896-1897$ & Civil engineer & Resigned \\
\hline August Karlson & 1899-1902 & $\begin{array}{l}\text { Diploma in engineering from the University of } \\
\text { Stockholm }\end{array}$ & $\begin{array}{l}\text { Contract termi- } \\
\text { nated }\end{array}$ \\
\hline Hugh Daniel Badcock & $1902-1909$ & MA in mathematics, University of Oxford & Resigned \\
\hline F. Walton Jameson & $1909-1920$ & Learnt trade in Durban & $\begin{array}{l}\text { Resigned because } \\
\text { of the other work }\end{array}$ \\
\hline
\end{tabular}

In Johannesburg, all five town engineers were selected on the basis of the application process, while in Pretoria only the appointments of Badcock and Jameson were based on formal applications. Lutz was a member of Pretoria's temporary town council and possibly the only qualified engineer on the council when he became the first town engineer. When Karlson was appointed in 1899, he was already a manager of Pretoria Waterworks and was invited to take on the responsibilities of a town engineer as well.

In nearly every case, previous experience played a significant role in the selection process, Lutz being the exception. Miles, although working at the time in England, had previous experience in South Africa. Grey had been working as a temporary town engineer and had a private practice in Johannesburg. As for Aburrow, he had worked in South Africa since 1879, first in Kimberley and then in Johannesburg. Leitch, although lacking municipal experience, had a long engineering career in governmental organisations and Andrews had been employed in the engineering department in Johannesburg for 12 years. Karlson had a great deal of experience and had worked in Sweden, France and Panama before coming to the Transvaal in 1892. Badcock arrived in South Africa during the Anglo-Boer War and 
was assistant engineer in Pretoria from 1900 to 1901, while Jameson was the borough engineer of Pietermaritzburg from 1902.

It appears that after the Anglo-Boer War, in both Johannesburg and Pretoria (now part of the newlyformed Transvaal Colony) there was a tendency to opt for town engineers from the United Kingdom, often at the expense of less experienced men. In 1901-1902 when this initially became evident, the Transvaal was still under martial law and the decision to appoint town officials was in the hands of the colonial governor. In Pretoria, for example, where the town council had their own favourite with a great deal of appropriate experience in South Africa, they were overruled by the colonial administration, who simply appointed their own candidate. Karlson also applied for the post but he was seen to be lacking the leadership qualities required for running the important department, although no one appeared to be questioning his abilities as an engineer.

In Johannesburg the situation was different. Aburrow was actually dismissed. It seems that he had clashed at least on some level with the new town clerk, Lionel Curtis, because there were questions aired about Aburrow's ability to work with other departments and Curtis virtually advocated his dismissal immediately after the war. At this time there seems to be a definite trend against those who had long experience of South African conditions. Curtis, for his part, said explicitly that the need was for new men from England.

If we look at the termination of the tenures of the town engineers, it seems that their task was far from easy. Two of the engineers, Miles and Aburrow, were dismissed; and two, Grey and Lutz, resigned because of alleged misconduct. With the benefit of hindsight, at least in the case of Aburrow, there was no misconduct on his side. Of the other three, Grey's actions appear to fall under the definition of corruption; such allegations, in the case of Miles and Lutz, are rather less clear. Lutz was exonerated of any misconduct and Miles had defenders who said that the sanitary board had been too eager to see misconduct were there was none.

Karlson was not allowed to remain in his position. Furthermore, the two engineers chosen after the war, Leitch and Badcock, both resigned and moved to other jobs. Leitch was chosen as a first chief engineer of the newly-established Rand Water Board and it can be speculated that one of the reasons he applied for that position was his inexperience in the politics of municipal engineering. He received a great deal of criticism, especially for his proposals for drainage and sewerage systems in Johannesburg; he might well have wanted an 'easier', less pressurised position. In Badcock's case his resignation was probably caused by Pretoria's retrenchment policy. Indeed, it was probably only Andrews who went from his post as an engineer straight into retirement. In 1920 Jameson was invited to take over as town engineer in Kimberley and as an added bonus he was allowed to maintain his private practice.

In summary, it can be said that during this period there were still some uncertainties in the job description and powers of the municipal engineer. Apparently the incumbent was an important official in the municipal structure but the town council could nevertheless dismiss him or force him to resign at very short notice. In these early days, it seems, it was unclear to municipal decision makers what qualities were necessary in a successful municipal engineer. Furthermore it certainly appears that the engineers themselves were unsure what was expected from them, or what kind of working environments 
awaited them in South African towns.

What also emerges clearly is that the members of the sanitary board in Johannesburg and the town council in Pretoria were taking their supervisory duties seriously. Having very limited resources both in Johannesburg and Pretoria, a sharp and diligent eye was kept on all expenses. The projects undertaken by the engineering departments were undeniably expensive; it was imperative that the cheapest tenders be accepted because money could not be wasted. All allegations of misconduct and corruption were taken extremely seriously - perhaps far more so than they are today. 